\title{
An Improved PV Output Forecasting Model by Using Weight Function: A Case Study in Cambodia
}

\section{Songkiate Kittisontirak, ${ }^{1}$ Aekkawat Bupi, ${ }^{1}$ Perawut Chinnavornrungsee, ${ }^{2}$ Kobsak Sriprapha, ${ }^{2}$ Pairash Thajchayapong, ${ }^{2}$ and Wisut Titiroongruang ${ }^{1}$}

${ }^{1}$ Faculty of Engineering, King Mongkut's Institute of Technology Ladkrabang, Chalongkrung Rd, Ladkrabang, Bangkok 10520, Thailand ${ }^{2}$ National Electronics and Computer Technology Center (NECTEC), National Science and Technology Development Agency (NSTDA), 112 Thailand Science Park, Thanon Phahonyothin, Tambon Khlong Nueng, Amphoe Khlong Luang, Pathum Thani 12120, Thailand

Correspondence should be addressed to Songkiate Kittisontirak; songkiate.kittisontirak@nectec.or.th

Received 4 April 2016; Revised 18 September 2016; Accepted 12 October 2016

Academic Editor: Leonardo Sandrolini

Copyright (C) 2016 Songkiate Kittisontirak et al. This is an open access article distributed under the Creative Commons Attribution License, which permits unrestricted use, distribution, and reproduction in any medium, provided the original work is properly cited.

This paper proposes a new concept to improve accuracy of PV forecasting model. The model was implemented by MATLAB/Simulink software using solar irradiance and module temperature as measurement parameters for calculation. The model was developed by single-diode equivalent circuits (5-p model) for simulated PV module power output and compared with other software programs for validation which showed correct PV characteristics. To achieve high accuracy, the model was improved by weight function using one-year measured data. The accuracy of our developed model was verified by comparison with four commercial simulator software programs and the results from real system which were measured and recorded for 1 year. It was found that the model output was in a good agreement with the measured data. This research can be utilized in another area by adjusting the PV equation with weight function of that area.

\section{Introduction}

At present, renewable energy has an important role in meeting the world energy balance. The need for renewable energy is rapidly increasing in the world, especially the solar energy resource such as solar cells due to its properties like being abundant, clean, pollution-free, and sustainable. The most important steps after installation of photovoltaic system are checking and maintenance. If we can estimate the energy production of PV system, it will be available to check the system fault by comparing the real data with estimated data. The models to estimate the energy production of PV system usually start from PV module's modeling.

Many researchers have provided the models of PV module and considered that PV model is mainly affected by the solar irradiance and module temperature [1]. In addition, single-diode equivalent circuits (4-p model) are commonly used in PV models [2-17]. These models have four parameters: photo current source, diode parallel, series resistance $R_{s}$, and shunt resistance $R_{\mathrm{sh}}$. However, the 4-p model ignores the effect of shunt resistance $\left(R_{\mathrm{sh}}\right)$. It was shown in case of current which is increasing with temperature effect to less accurate prediction of current than five-parameter model. Then, the parallel resistance is thus introduced in the model [14, 18-34]. After that, the model was improved for better curve-fitting and accuracy by two-diode equivalent circuit but increases the number of computed parameters [35-42].

In this paper, we proposed a new concept to improve high accuracy of PV forecasting model. The main contribution of this paper is implementing the PV model by using weight function which is obtained by one-year measured data. Our developed model is based on single-diode equivalent circuits (5-p model) which is simplified and not complicated. The verification of the proposed forecasting model has been confirmed by comparison with four simulator software programs and measured data in Cambodia. It was found that our developed model has high precision. 
TABLE 1: The ideal factor is dependent on PV technology.

\begin{tabular}{lc}
\hline List & Data \\
\hline Mono c-Si & 1.2 \\
Poly c-Si & 1.3 \\
a-Si:H Single junction & 1.8 \\
a-Si:H Double junction & 3.3 \\
a-Si:H Tripple junction & 5.0 \\
CdTe & 1.5 \\
CIS & 1.5 \\
GaAs & 1.3 \\
\hline
\end{tabular}

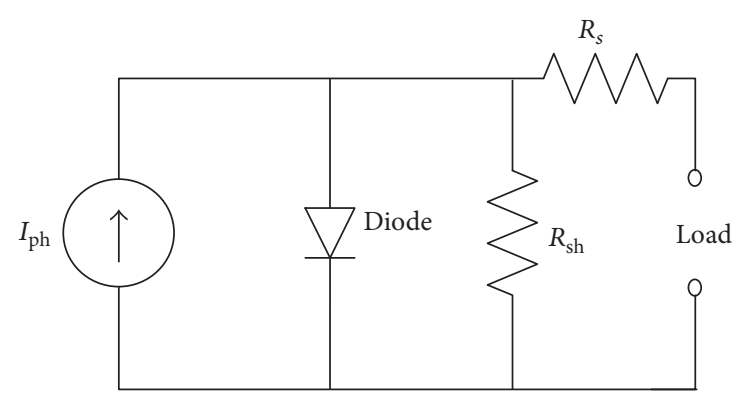

FIgURE 1: Photovoltaic equivalent circuit.

\section{Mathematical Model of PV System}

2.1. One-Diode Equivalent Circuit. Figure 1 shows the PV equivalent circuit with one diode used in this model. This is the so-called five-parameter (5-p) model. The model consists of a photo current $\left(I_{\mathrm{ph}}\right)$, a diode, a parallel resistance $\left(R_{\mathrm{sh}}\right)$ expressing a leakage current, and a series resistance $\left(R_{s}\right)$ describing an internal resistance to the current flow and acceptable levels of accuracy. It is used to estimate the PV power output, as shown in (1)-(6):

$$
\begin{aligned}
I= & I_{\mathrm{ph}}-I_{0}\left[\exp \left(\frac{q\left(V+I \cdot R_{s}\right)}{N \cdot K \cdot T}-1\right)\right] \\
& -\frac{\left(V+I \cdot R_{s}\right)}{R_{\mathrm{sh}}}
\end{aligned}
$$

where $I_{\mathrm{ph}}$ is photo current $(\mathrm{A}), I_{0}$ is the leakage current of the diode $(\mathrm{A}), q$ is electron charge $\left(1.602 \times 10^{-19} \mathrm{C}\right), k$ is Boltzmann constant $\left(1.381 \times 10^{-23} \mathrm{~J} / \mathrm{K}\right), T$ is actual cell temperature $(\mathrm{K}), R_{\mathrm{s}}$ is series resistance $(\Omega)$, and $R_{\mathrm{sh}}$ is shunt resistance $(\Omega)$ and the ideal factor chosen from Table 1 according to the PV technology involved.

$$
V=V_{m}-B_{s}\left(T_{m}-T_{0}\right)
$$

where $V_{m}$ is maximum voltage $(\mathrm{V}), B_{s}$ is temperature coefficient of voltage $\left(\mathrm{V} /{ }^{\circ} \mathrm{C}\right), T_{m}$ is cell temperature $\left({ }^{\circ} \mathrm{C}\right)$, and $T_{0}$ is ambient temperature:

$$
I_{\mathrm{ph}}=\frac{G}{G_{\mathrm{ref}}}\left(I_{\mathrm{ph}, \mathrm{ref}}+\mu_{\mathrm{sc}} \cdot\left(T-T_{\mathrm{ref}}\right)\right) .
$$

$I_{\mathrm{ph}}$ is photo current depending on the solar irradiance and cell temperature as (3), where $G$ is solar irradiance $\left(\mathrm{W} / \mathrm{m}^{2}\right), G_{\text {ref }}$ is solar irradiance at STC $\left(1000 \mathrm{~W} / \mathrm{m}^{2}\right), \mu_{\mathrm{sc}}$ is temperature coefficient of current $\left(\mathrm{A} /{ }^{\circ} \mathrm{C}\right), I_{\mathrm{ph}, \text { ref }}$ is photo current at STC (A), and $T_{\text {ref }}$ is reference temperature at STC $\left(25^{\circ} \mathrm{C}\right)$.

$I_{0}$ is function of module temperature and defined by

$$
I_{0}=I_{0, \text { ref }}\left(\frac{T_{c}}{T_{c, \text { ref }}}\right)^{3} \exp \left[\left(\frac{q \cdot E_{g}}{A \cdot K}\right)\left(\frac{1}{T_{c, \text { ref }}}-\frac{1}{T_{c}}\right)\right]
$$

$I_{0, \text { ref }}$ is energy band gap and defined by

$$
I_{0, \text { ref }}=I_{\text {sc,ref }} \exp \left(\frac{q\left(-V_{\mathrm{oc}, \mathrm{ref}}\right)}{N \cdot K \cdot T}\right)
$$

$R_{\mathrm{sh}}$ is defined by

$$
R_{\mathrm{sh}}=\frac{V_{m}+\left(I_{m, \mathrm{ref}} \cdot R_{s}\right)}{I_{\mathrm{sc}, \text { ref }}-I_{\mathrm{sc}, \text { ref }}\left\{\exp \left[q\left(V_{m, \mathrm{ref}}+I_{m, \mathrm{ref}} \cdot R_{s}-V_{\mathrm{oc}, \mathrm{ref}}\right) / N \cdot K \cdot T\right]\right\}+I_{\mathrm{sc}, \text { ref }}\left\{\exp q\left(-V_{\mathrm{oc}, \mathrm{ref}}\right) / N \cdot K \cdot T\right\}-\left(P_{m} / V_{m, \text { ref }}\right)} .
$$

2.2. Performance of Simulation Model. In this study, the RMSE (Root Mean Square Error) technique was used to evaluate the accuracy. This technique is widely recognized in many works [43]. The parameter was defined by

$$
\mathrm{RMSE}=\sqrt{\frac{1}{n} \sum_{i=1}^{n}\left(\frac{f_{i}-y_{i}}{y_{i}}\right)^{2}},
$$

where the measured data is $y_{i}$ and the prediction data is $f_{i}$.

\section{Evolution of Modeling}

Figure 2 shows the structure of PV power system simulation model with MATLAB/Simulink software. The model used two main parameters for calculation which has significant effect on the PV efficiency, namely, solar irradiance and module temperature. The simulation model was developed by single-diode equivalent circuits (5-p model) for simulated PV module power output and compared with other commercial software simulations to confirm the modeling which showed 


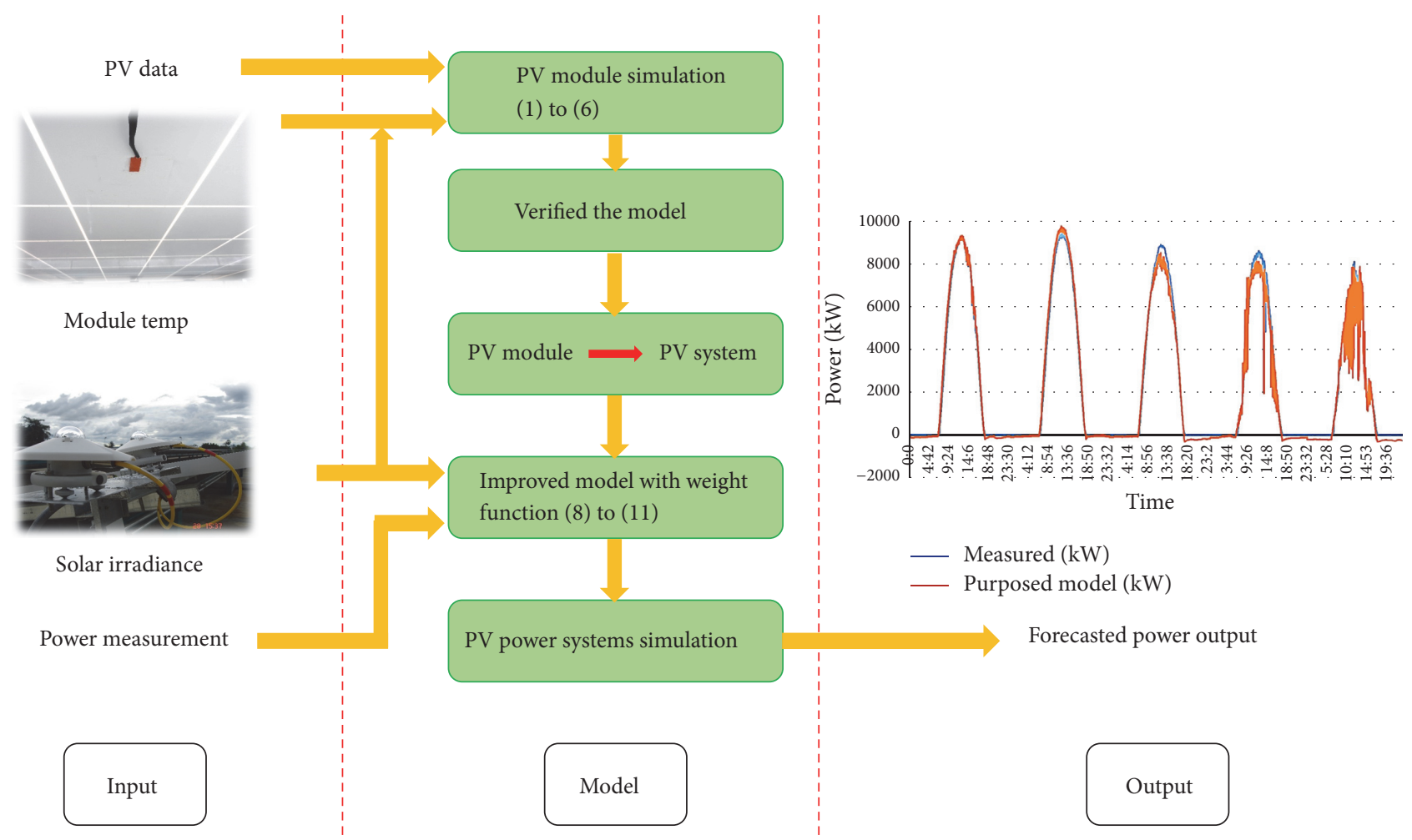

FIGURE 2: Structure of PV system simulation model.

the correct characteristic of PV. After that, to increase more accuracy, model efficiency was improved by using weight function which was obtained by one-year measured data as shown in Figure 3. It was found that by using weight function with our developed model, the accuracy was very high compared with other simulated model without weight function to simulate PV power system and verify by comparing with four software simulators and one-year measured data.

The procedures implemented in improving accuracy of our developed model are as follows.

Step 1. Calculate the average annual measured output power $\left(P_{m d}\right)$ and average annual output power simulated $\left(P_{s d}\right)$ at one value of solar irradiance $(G)$ on the day d as follows:

$$
\begin{gathered}
\bar{P}_{m y}(G)=\frac{1}{N_{y}} \sum_{d=1}^{N_{y}} P_{m d}, \\
\bar{P}_{s y}(G)=\frac{1}{N_{y}} \sum_{d=1}^{N_{y}} P_{s d},
\end{gathered}
$$

where $N_{y}$ is the number of days during the one-year time period.

Step 2. Created equation in relation with solar irradiance and average annual measured output power $\left(P_{m d}\right)$ and average

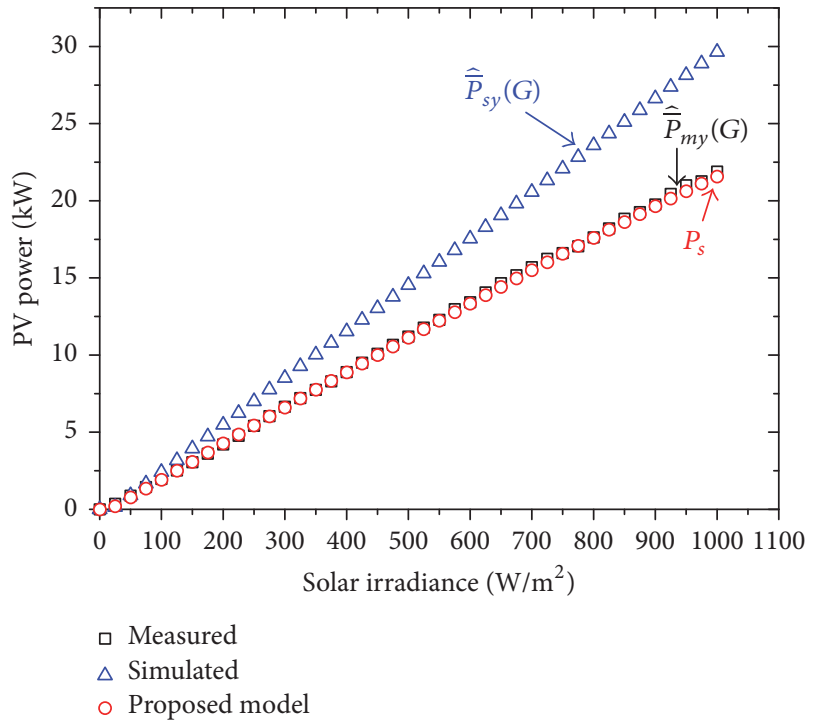

FIGURE 3: Improvement of our developed model with weight function.

annual output power simulated $\left(P_{s d}\right)$. Then, using polynomial equation for fitting the data is as shown in Table 2:

$$
\hat{\bar{P}}_{m y}(G), \hat{\bar{P}}_{s y}(G)=\text { Intercept }+A_{1} G+A_{2} G^{2}+A_{3} G^{3},
$$




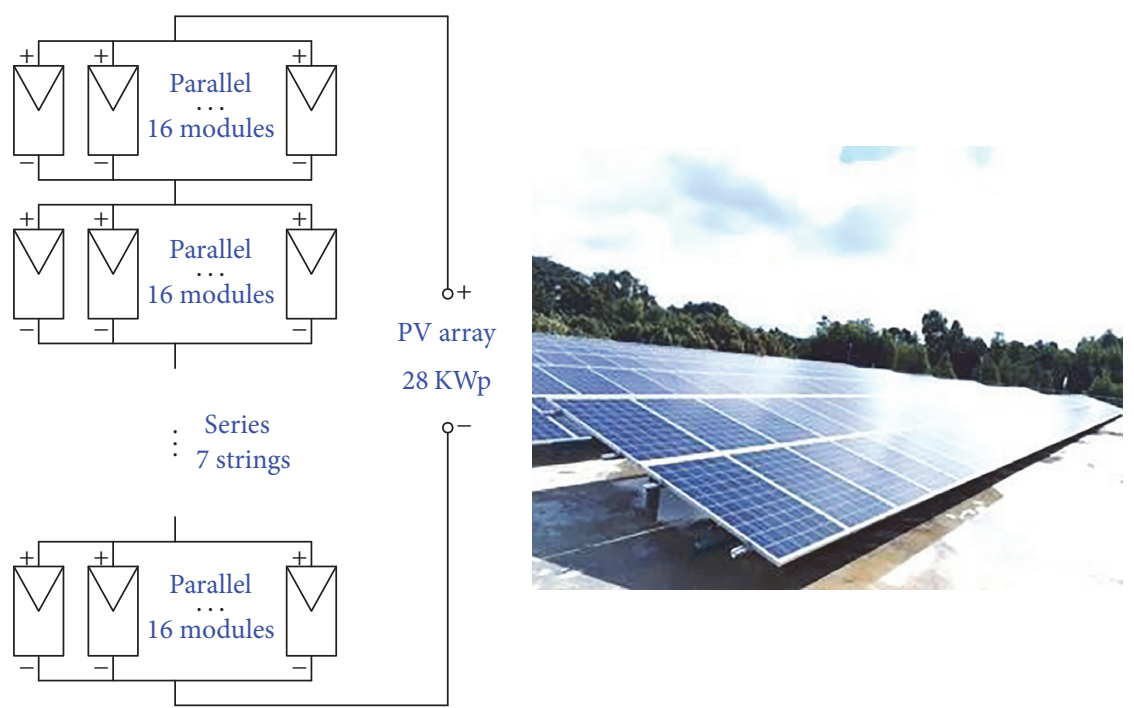

FIGURE 4: Schematic diagram and PV system installed in Cambodia.

TABLE 2: The data used in our developed model.

\begin{tabular}{lcc}
\hline & Parameter & Value \\
\hline \multirow{3}{*}{ Measured } & Intercept & -0.2001 \\
& $A_{1}$ & 0.0219 \\
& $A_{2}$ & $3.00 e-6$ \\
& $A_{3}$ & $3.00 e-9$ \\
\hline \multirow{3}{*}{ Simulated } & Intercept & -0.4266 \\
& $A_{1}$ & 0.0292 \\
& $A_{2}$ & $2.00 e-6$ \\
& $A_{3}$ & $1.00 e-9$ \\
\hline \multirow{3}{*}{ Weight function } & Intercept & $2.27 e-1$ \\
& $A_{1}$ & $7.30 e-3$ \\
& $A_{2}$ & $-1.00 e-6$ \\
& $A_{3}$ & $2.00 e-9$ \\
\hline
\end{tabular}

where $\widehat{\bar{P}}_{m y}(G), \hat{\bar{P}}_{s y}(G)$ is function of annual PV power output from measured and simulated, respectively.

Step 3. From (10), the weight function was generated, which was used to improve the accuracy of model as follows.

Equation (11) shows that the simulated PV power output used in our developed model $\left(P_{s}\right)$ has improved the accuracy with weight function:

$$
\begin{aligned}
P_{w} & =\widehat{\bar{P}}_{m y}(G)-\widehat{\bar{P}}_{s y}(G), \\
P_{s} & =\hat{\bar{P}}_{s y}(G)+P_{w},
\end{aligned}
$$

where $P_{w}$ is weighted function.

\section{Validation Results and Discussion}

4.1. System Introduction. In this study, our developed model is verified by using one-year measured data which was collected from a PV system installed on the ground-mounted fixed-array system in Kampong Chheuteal High School, Kingdom of Cambodia $\left(12^{\circ} 52^{\prime} 55.6^{\prime \prime}\right.$ north latitude and $105^{\circ} 04^{\prime} 09.6^{\prime \prime}$ east longitude).

The system consists of 112 PV modules, $250 \mathrm{Wp} /$ module; each string consist of $16 \mathrm{PV}$ modules connected in series and 7 strings are connected in parallel. The PV system has monitoring systems to monitor and collect data for all parameters recorded every 5 minutes. The PV module specifications are shown in Table 3 and the schematic diagram is shown in Figure 4.

4.2. Simulation Result. In this study, the model was developed by simplifying PV equation and comparing with other simulator software (PVsyst) by varying solar irradiance and module temperature and plotting the results on $I-V$ and $P-V$ curves to test for its PV characteristics correctness. After that, the simulation model was improved in order to obtain high accuracy by using weight function which was obtained by one year measured data. Finally, the simulation results of our developed model were verified by comparing with four software simulators and actual measured data.

\subsubsection{Simulation of PV Module}

(i) Various Solar Irradiance and Constant Temperature. The simulation results of energy production from PV module were generated and compared to the simulation of PVsyst at the solar irradiance which varies $200,400,600,800$, and $1000 \mathrm{~W} / \mathrm{m}^{2}$ where the temperature of the PV modules was constant $45^{\circ} \mathrm{C}$.

From the results, it was found that the simulated results of energy production from PV module with the equations (1) and (3)-(5) have shown the correct PV characteristics. The PV current is directly proportional to solar irradiance and voltage was slightly increasing. This can be seen in Figure 5.

Table 4 shows comparison of the simulation results from our developed model with other software programs at various 
TABLE 3: The information of the PV system.

\begin{tabular}{lcccc}
\hline System & Rate capacity & Angle & Azimuth & Structure \\
& $28 \mathrm{kWp}$ & 13.00 & South & $\begin{array}{c}\text { 16 module/string } 7 \text { strings in } \\
\text { parallel }\end{array}$ \\
\hline \multirow{2}{*}{ Module } & Company & Peak power & $T_{c}$ of $V_{\mathrm{oc}}$ & $T_{c}$ of $I_{\mathrm{sc}}$ \\
& Solartron & $250 \mathrm{~W}$ & $-0.31 \% /{ }^{\circ} \mathrm{C}$ & $0.05 \% /{ }^{\circ} \mathrm{C}$ \\
\hline
\end{tabular}

TABLE 4: Comparing the simulation results with other software programs by varying the solar irradiance.

\begin{tabular}{lccc}
\hline Solar irradiance $\left(\mathrm{W} / \mathrm{m}^{2}\right)$ & Other software programs $(\mathrm{W})$ & Our developed model $(\mathrm{W})$ & RMSE \\
\hline 200 & 45.38 & 42.56 & 0.062 \\
400 & 90.72 & 88.52 & 0.024 \\
600 & 135.35 & 135.10 & 0.002 \\
800 & 182.09 & 181.73 & 0.002 \\
1000 & 223.93 & 228.00 & 0.018 \\
\hline
\end{tabular}

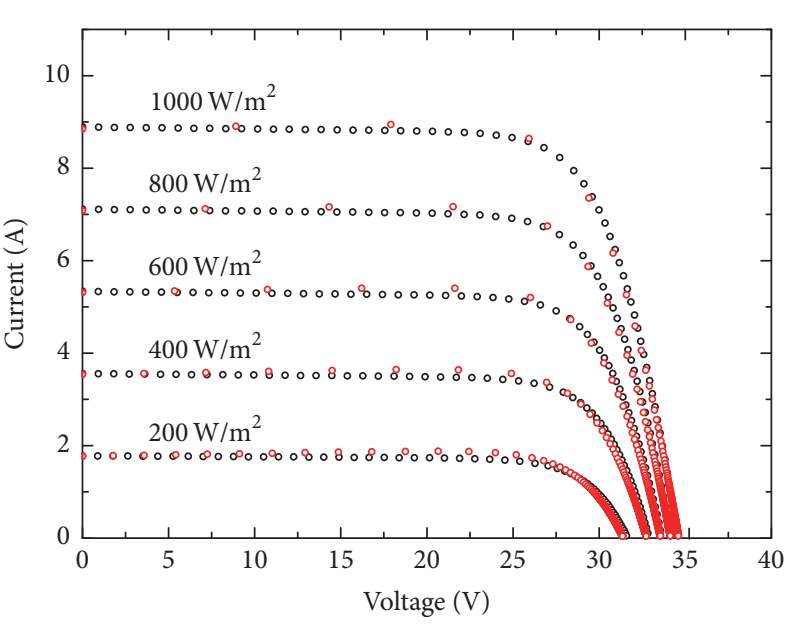

- PVsyst software

- Proposed model

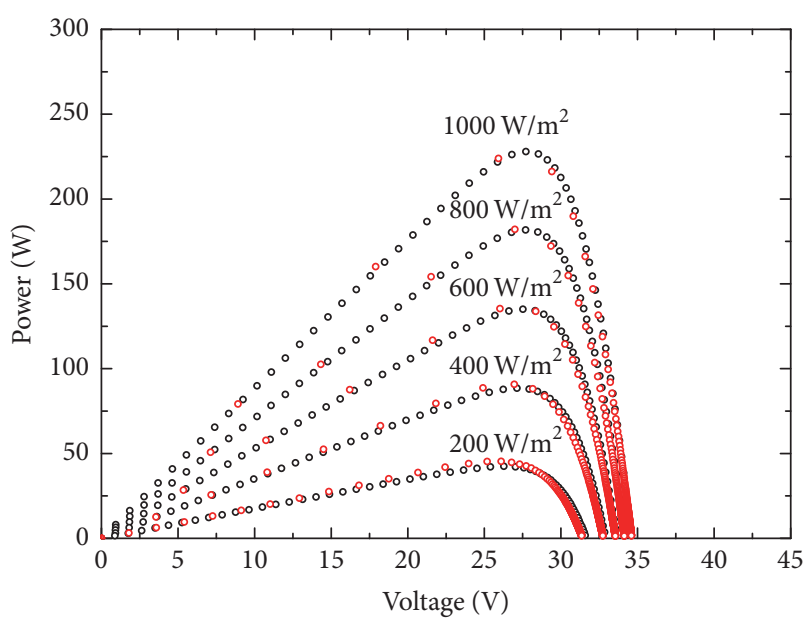

- PVsyst software

- Proposed model

Figure 5: PV module's $I$ - $V$ curves and $P-V$ curves under difference solar irradiance (module temperature $=45^{\circ} \mathrm{C}$ ).

solar irradiances. It can be seen that RMSE values are very low in range $(0.002$ to 0.062$)$.

(ii) Various Temperature and Constant Irradiance. The simulation results of energy production from PV module were compared to the simulation of PVsyst at the module temperature which varies $10,25,40,55$, and $70^{\circ} \mathrm{C}$ where the solar irradiance was $1000 \mathrm{~W} / \mathrm{m}^{2}$.

Figure 6 shows the PV module's $I-V$ and $P-V$ curves for various module temperatures and constant solar irradiance of $1000 \mathrm{~W} / \mathrm{m}^{2}$. It was found that as the module temperature increased, the voltage decreased due to temperature coefficient $\left(T_{c}\right)$ in accordance with technology of the PV.

Table 5 shows the simulation results in comparison with other software programs at various solar irradiances. It can be seen that RMSE values are in the range of 0.007 to 0.029 .

4.2.2. Simulation of $P V$ System. To verify the accuracy of our developed model, the simulation results were compared with the one-year collected data from PV system installed in Cambodia. First, the daily simulation result was compared with two weather conditions, namely, sunny and cloudy days, later monthly simulation results with monthly energy production of PV system.

(i) Daily PV System Output Simulation. In case of sunny day, 15 Jan 2015, the simulation result and measured data of PV system on that day are shown in Figure 7. The RMSE value is very low (0.037) and is lower than the cloudy day case.

For cloudy day, 31 Mar 2015, it was found that the simulation of PV power curve was matching very well with measured data and was changing according to solar irradiance; however, some difference at certain point was noted due to mismatch of module temperature and solar irradiance recording equipment's error. The RMSE value is 0.059, as shown in Figure 8.

The accuracy of our developed model for both cases is shown in Table 6. 
TABLE 5: Comparing the simulation results with other software programs by varying the module temperature.

\begin{tabular}{lccc}
\hline Module temperature $\left({ }^{\circ} \mathrm{C}\right)$ & Other software programs $(\mathrm{W})$ & Our developed model $(\mathrm{W})$ & RMSE \\
\hline 10 & 266.54 & 226.04 & 0.015 \\
25 & 250.00 & 250.16 & 0.001 \\
40 & 227.00 & 233.65 & 0.029 \\
55 & 215.26 & 216.52 & 0.006 \\
70 & 197.46 & 198.81 & 0.007 \\
\hline
\end{tabular}

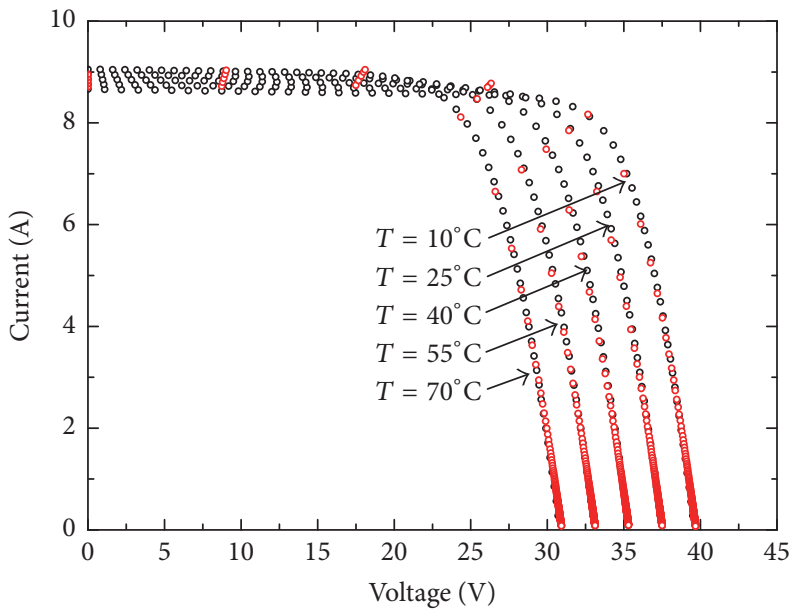

- PVsyst software

- Proposed model

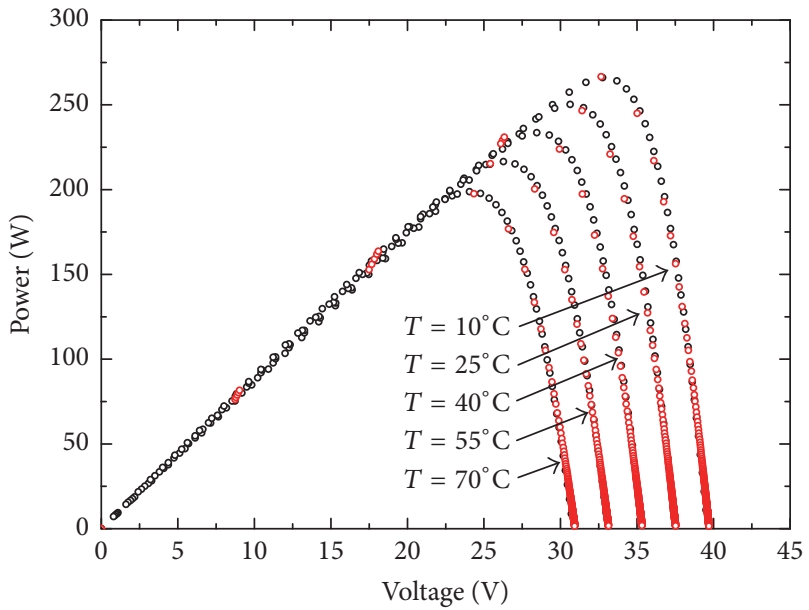

- PVsyst software

- Proposed model

FIgURE 6: PV module's $I-V$ curves and $P-V$ curves under different module temperature (solar irradiance $\left.=1000 \mathrm{~W} / \mathrm{m}^{2}\right)$.

TABLE 6: Comparison between simulation results on sunny day and cloudy day.

\begin{tabular}{lc}
\hline Months & RMSE \\
\hline Case 1: sunny day & 0.037 \\
Case 2: cloudy day & 0.059 \\
\hline
\end{tabular}

(ii) Monthly PV Power Output Simulation. Figure 9 shows the accuracy of our developed model in comparison with 12 months measured data. It is a well-known fact that PV power production changes according to solar irradiance. From the result, it was found that the power output was less than PV installed due to the losses in system such as capture loss, temperature loss, and system loss. In this study, the thermal loss was included in the model. The RMSE rages from 0.03 to 0.05 .

Table 7 shows that the RMSE values are very low, indicating a very good agreement between simulation results and measured data.

The results from 12 months of energy production in Cambodia showed that the average energy production is 3.08 MWh/month and 36.90 MWh/year. As shown in Figure 10, the accuracy of our developed model has been verified by comparing its output with four simulators software and one-year measured data. It was found that the simulation results of our developed model show the average energy production is $3.03 \mathrm{MWh} / \mathrm{month}$ and $36.38 \mathrm{MWh} /$ year. And the results from other commercial software simulator showed that average energy production is $3.44 \mathrm{MWh} / \mathrm{month}$, 3.32 MWh/month, 3.77 MWh/month, and 3.18 MWh/month, respectively, as shown in Figure 10.

Table 8 shows the accuracy of our developed model against one-year measured data and other simulator software results. The RMSE ranges from 0.03 to 0.05 and average RMSE is 0.04 .

From the result, it was found that our developed model and 4 software simulators tend to change in the same way from measured data shown the accuracy of PV characteristics but there was a difference from the perfect graph due to using weight function which showed a high accuracy compared to other software simulations.

Our developed model accuracy can be attributed to the weight function of one-year measured data. Our developed model can be applied to other areas by adjusting the PV equation with measured data of that area.

\section{Conclusion}

This paper proposes the PV model with improved efficiency through weight function with one-year measured data. The accuracy of our developed model was confirmed by comparison with four commercial software simulations and actual one-year measured data. The first model in our study was developed by generic PV equation and simulation results 
TABLE 7: The efficiencies of the proposed model.

\begin{tabular}{|c|c|c|c|c|c|c|c|c|c|c|c|c|c|}
\hline Months & Jan & Feb & Mar & Apr & May & Jun & Jul & Aug & Sep & Oct & Nov & Dec & Avg. \\
\hline RMSE & 0.05 & 0.03 & 0.04 & 0.03 & 0.03 & 0.04 & 0.04 & 0.04 & 0.04 & 0.03 & 0.05 & 0.04 & 04 \\
\hline
\end{tabular}

TABLE 8: Comparisons of measured data with other simulators and our developed simulated model.

\begin{tabular}{|c|c|c|c|c|c|c|c|c|c|c|c|c|c|c|}
\hline \multirow{2}{*}{ Months } & \multicolumn{13}{|c|}{ Energy production (MWh) } & \multirow{2}{*}{ RMSE } \\
\hline & Jan & Feb & Mar & Apr & May & Jun & Jul & Aug & Sep & Oct & Nov & Dec & Avg. & \\
\hline Measured & 3.26 & 2.95 & 3.63 & 3.18 & 3.43 & 3.14 & 2.58 & 2.94 & 2.61 & 2.69 & 3.21 & 3.28 & 3.08 & - \\
\hline PVsyst & 3.95 & 3.56 & 3.84 & 3.68 & 3.39 & 3.06 & 3.13 & 3.11 & 3.06 & 3.28 & 3.49 & 3.75 & 3.44 & 0.13 \\
\hline Homer & 3.75 & 3.43 & 3.70 & 3.54 & 3.27 & 2.95 & 3.02 & 3.00 & 2.95 & 3.19 & 3.37 & 3.65 & 3.32 & 0.10 \\
\hline BlueSol Express & 4.11 & 3.91 & 4.26 & 4.12 & 3.84 & 3.45 & 3.51 & 3.48 & 3.37 & 3.58 & 3.69 & 3.95 & 3.77 & 0.23 \\
\hline PVWATTS & 3.49 & 3.31 & 3.85 & 3.34 & 3.02 & 2.92 & 2.87 & 2.70 & 2.89 & 2.99 & 3.31 & 3.49 & 3.18 & 0.08 \\
\hline Proposed model & 3.37 & 2.87 & 3.51 & 3.04 & 3.28 & 3.00 & 2.49 & 2.86 & 2.73 & 2.79 & 3.05 & 3.38 & 3.03 & 0.04 \\
\hline
\end{tabular}

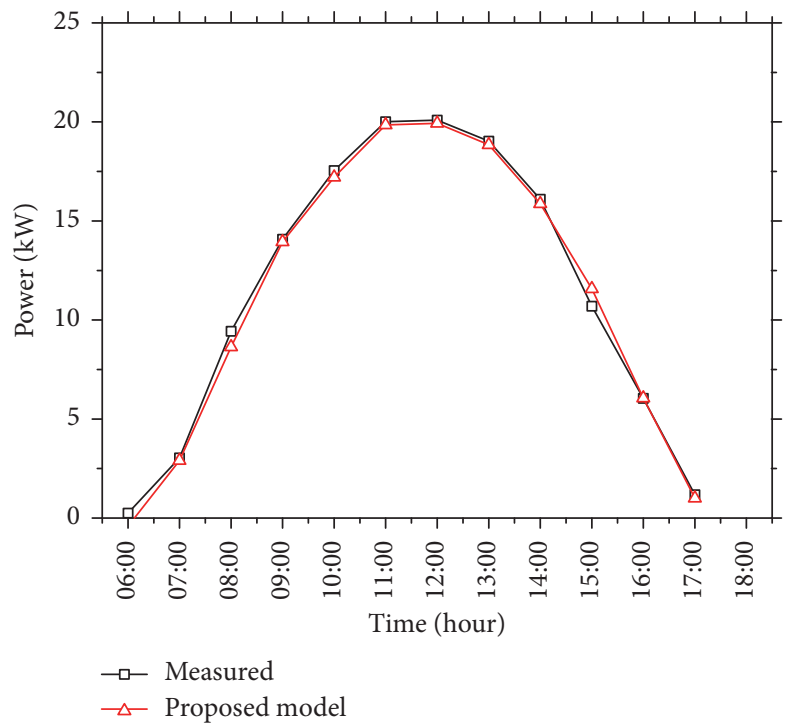

FIGURE 7: Prediction and measured PV power output on 15th Jan 2015 (sunny day).

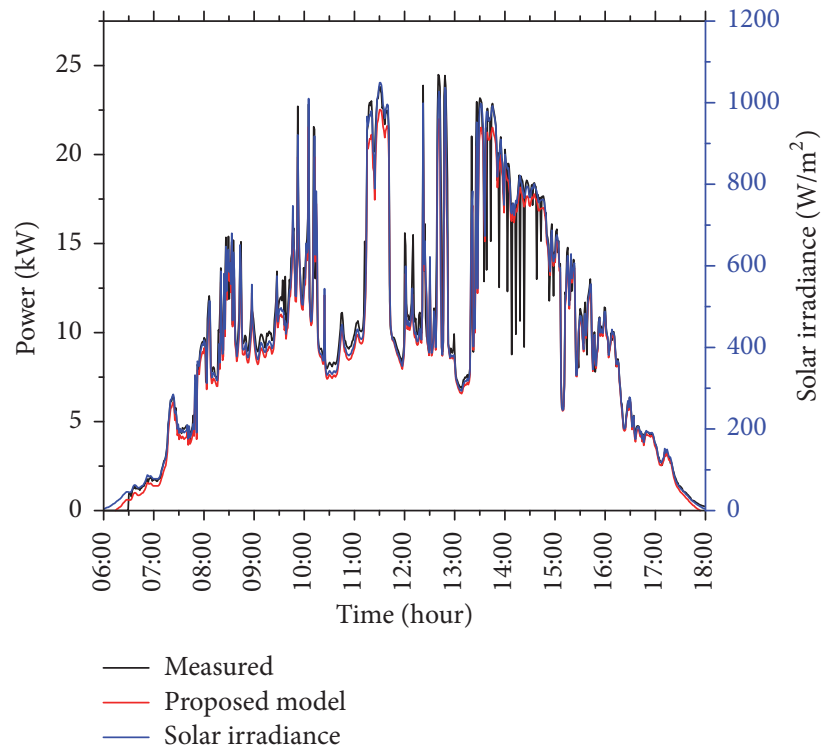

FIGURE 8: Prediction and measured PV power output on 31st Mar 2015 (cloudy day). 


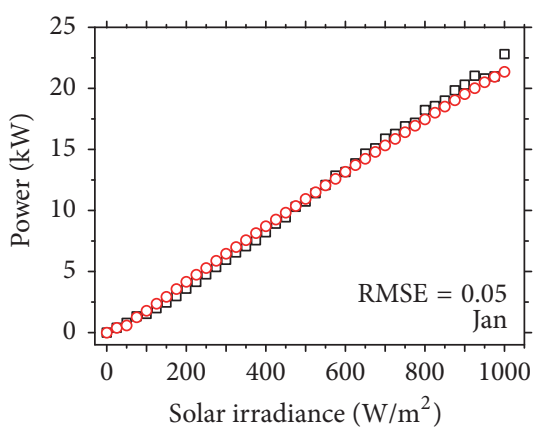

- Measured

- Proposed model

(a)

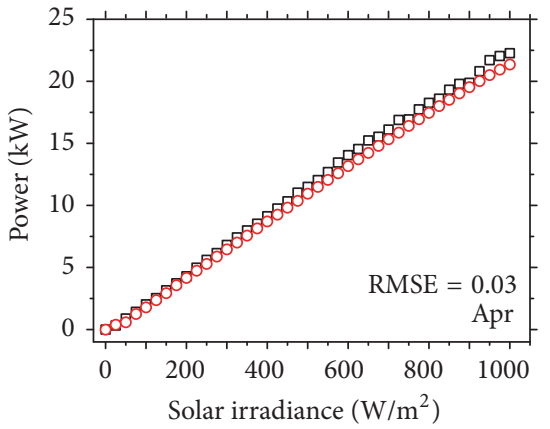

口 Measured

- Proposed model

(d)

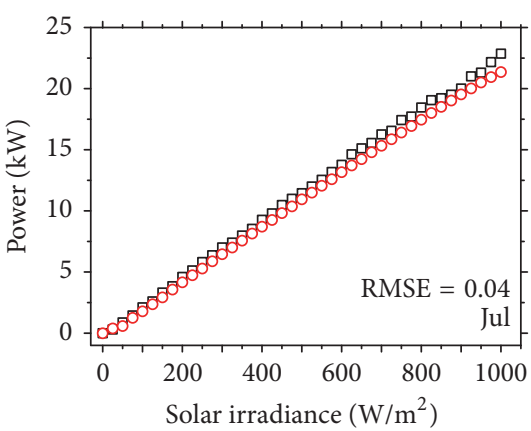

๑ Measured

o Proposed model

(g)

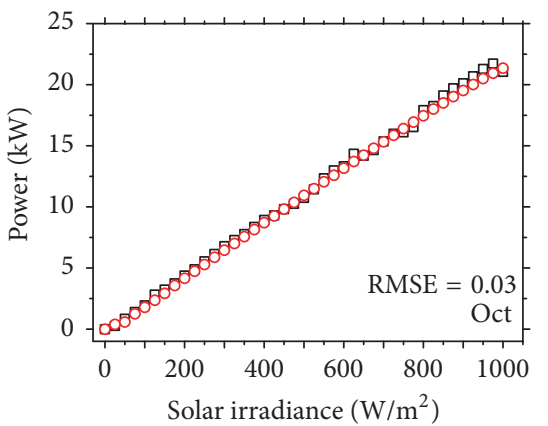

口 Measured

○ Proposed model

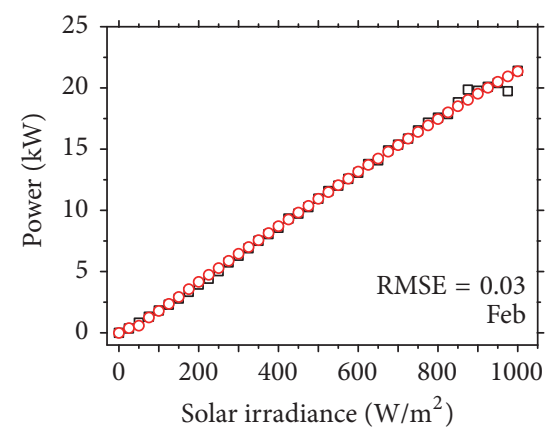

口 Measured

- Proposed model

(b)

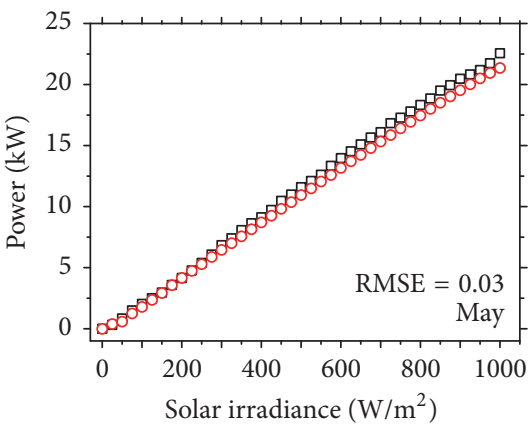

$\square$ Measured

- Proposed model

(e)

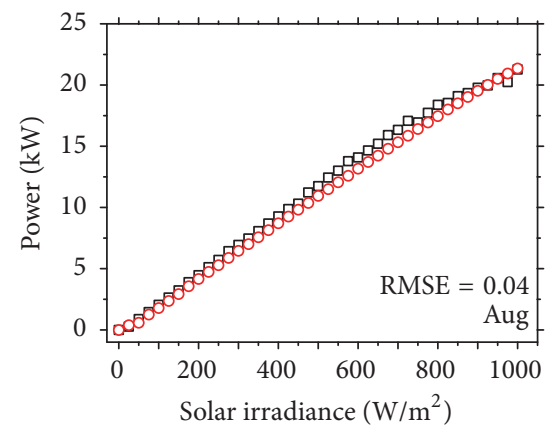

口 Measured

o Proposed model

(h)

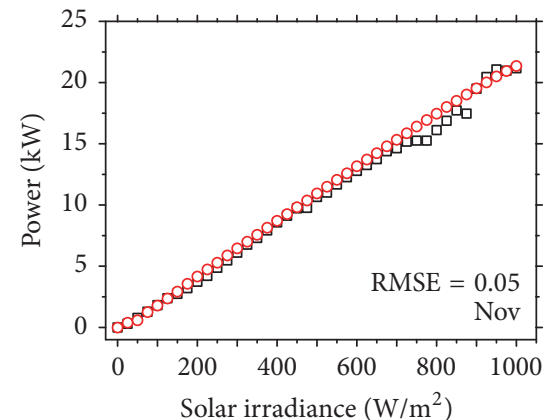

口 Measured

○ Proposed model

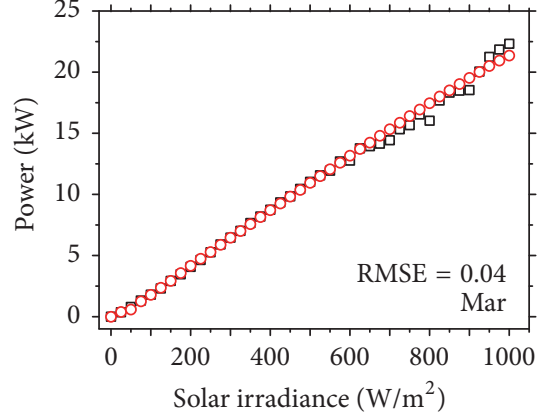

口 Measured

o Proposed model

(c)

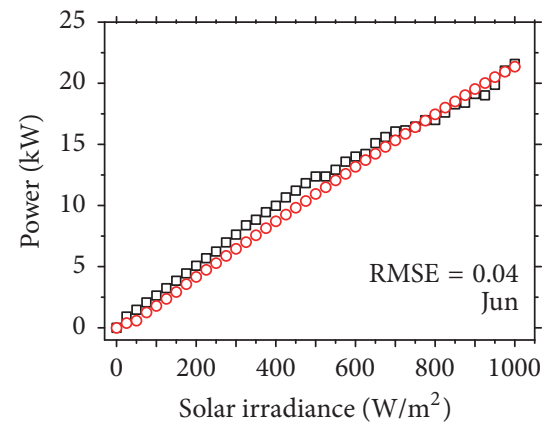

口 Measured

o Proposed model

(f)

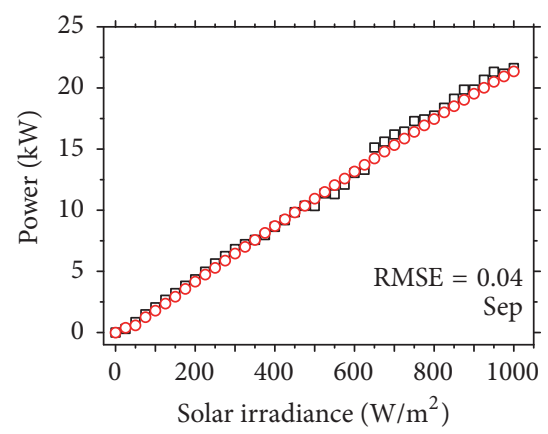

口 Measured

o Proposed model

(i)

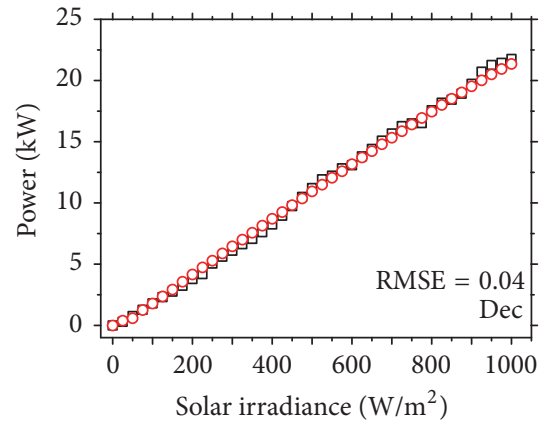

口 Measured

- Proposed model

FIGURE 9: Comparisons of the measured data and simulated PV power output. 


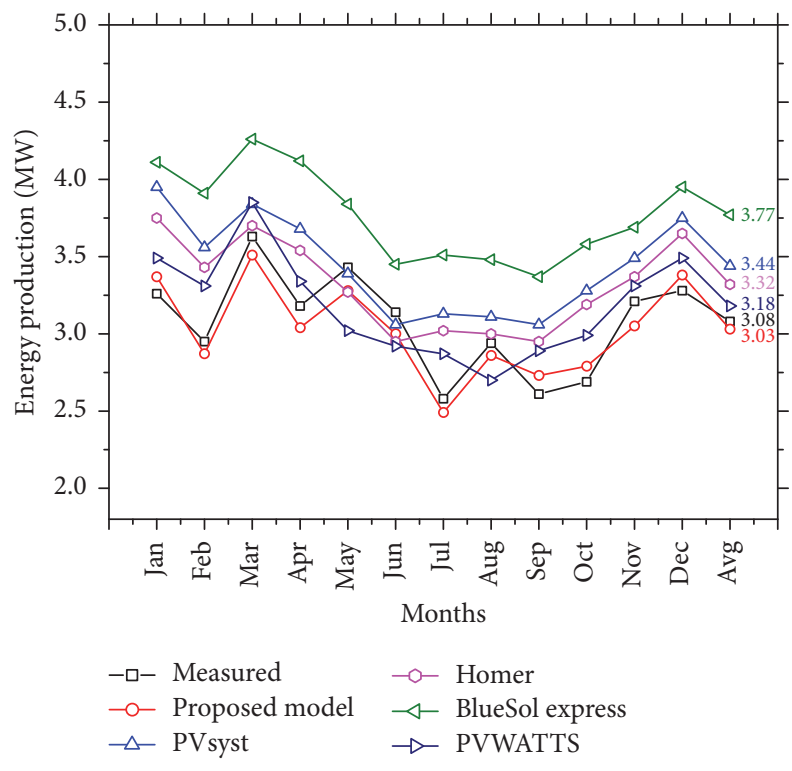

FIGURE 10: Simulated and measured monthly PV power output.

were compared with other software. The simulation result of PV model showed that the PV characteristic is correct and fits with other software. Later, the model was improved for accuracy by weight function.

The accuracy of our developed model was verified by comparison with four commercial software simulations and the real results from one-year measured data. The result clearly shows that our developed model has a very high accuracy. The RMSE ranges from 0.03 to 0.05 and average RMSE is 0.04 , which is less than other simulators software.

\section{Competing Interests}

The authors declare that they have no competing interests.

\section{References}

[1] R. Messenger and J. Ventre, Photovoltaic System Engineering, CRC Press, Boca Raton, Fla, USA, 2000.

[2] M. G. Villalva, J. R. Gazoli, and E. R. Filho, "Comprehensive approach to modeling and simulation of photovoltaic arrays," in Proceedings of the Power Electronics Conference, pp. 1244-1254, 2009.

[3] Y. Jiang, J. A. A. Qahouq, and M. Orabi, "Matlab/Pspice hybrid simulation modeling of solar PV cell/module," in Proceedings of the 26th Annual IEEE Applied Power Electronics Conference and Exposition (APEC '11), pp. 1244-1250, March 2011.

[4] R. Chenni, M. Makhlouf, T. Kerbache, and A. Bouzid, "A detailed modeling method for photovoltaic cells," Energy, vol. 32, no. 9, pp. 1724-1730, 2007.

[5] S. B. Dongue, D. Njomo, J. G. Tamba, and L. Ebengai, "Modeling of electrical response of illuminated crystalline photovoltaic modules using four- and five-parameter models," International Journal of Emerging Technology and Advanced Engineering, vol. 2, pp. 612-619, 2012.
[6] Y. T. Tan, D. S. Kirschen, and N. Jenkins, "A model of PV generation suitable for stability analysis," IEEE Transactions on Energy Conversion, vol. 19, no. 4, pp. 748-755, 2004.

[7] A. Mellit, M. Benghanem, and S. A. Kalogirou, "Modeling and simulation of a stand-alone photovoltaic system using an adaptive artificial neural network: proposition for a new sizing procedure," Renewable Energy, vol. 32, no. 2, pp. 285-313, 2007.

[8] L. Gonzalez and M. Francisco, Model of Photovoltaic Module in Matlab, CIBELEC, 2005.

[9] Y. Yusof, S. H. Sayuti, M. A. Latif, and M. Z. C. Wanik, "Modeling and simulation of maximum power point tracker for photovoltaic system," in Proceedings of the National Power and Energy Conference (PECon '04), pp. 88-93, Kuala Lumpur, Malaysia, November 2004.

[10] Y.-C. Kuo, T.-J. Liang, and J.-F. Chen, "Novel maximum-powerpoint-tracking controller for photovoltaic energy conversion system," IEEE Transactions on Industrial Electronics, vol. 48, no. 3, pp. 594-601, 2001.

[11] R. L. Chakrasali, V. R. Sheelavant, and H. N. Nagaraja, "Network approach to modeling and simulation of solar photovoltaic cell," Renewable and Sustainable Energy Reviews, vol. 21, pp. 84-88, 2013.

[12] A. A. Ghoneim, "Design optimization of photovoltaic powered water pumping systems," Energy Conversion and Management, vol. 47, no. 11-12, pp. 1449-1463, 2006.

[13] Q. Kou, S. A. Klein, and W. A. Beckman, "A method for estimating the long-term performance of direct-coupled PV pumping systems," Solar Energy, vol. 64, no. 1-3, pp. 33-40, 1998.

[14] A. N. Celik and N. Acikgoz, "Modelling and experimental verification of the operating current of mono-crystalline photovoltaic modules using four- and five-parameter model," Applied Energy, vol. 84, no. 1, pp. 1-15, 2007.

[15] A. Chatterjee, A. Keyhani, and D. Kapoor, "Identification of photovoltaic source models," IEEE Transactions on Energy Conversion, vol. 26, no. 3, pp. 883-889, 2011.

[16] M. Karamirad, M. Omid, R. Alimardani, H. Mousazadeh, and S. N. Heidari, "ANN based simulation and experimental verification of analytical four- and five-parameters models of PV modules," Simulation Modelling Practice and Theory, vol. 34, pp. 86-98, 2013.

[17] W. Xiao, W. G. Dunford, and A. Capel, "A novel modeling method for photovoltaic cells," in Proceedings of the IEEE 35th Annual Power Electronics Specialists Conference (PESC '04), vol. 3, pp. 1950-1956, June 2004.

[18] V. Lo Brano, A. Orioli, G. Ciulla, and A. Di Gangi, "An improved five-parameter model for photovoltaic modules," Solar Energy Materials and Solar Cells, vol. 94, no. 8, pp. 1358-1370, 2010.

[19] T. Ma, H. Yang, L. Lu, and J. Peng, "Technical feasibility study on a standalone hybrid solar-wind system with pumped hydro storage for a remote island in Hong Kong," Renewable Energy, vol. 69 , pp. 7-15, 2014.

[20] M. G. Villalva, J. R. Gazoli, and E. R. Filho, "Comprehensive approach to modeling and simulation of photovoltaic arrays," IEEE Transactions on Power Electronics, vol. 24, no. 5, pp. 11981208, 2009.

[21] T. Ma, H. Yang, and L. Lu, "Development of a model to simulate the performance characteristics of crystalline silicon photovoltaic modules/strings/arrays," Solar Energy, vol. 100, pp. 31-41, 2014

[22] J. Bai, S. Liu, Y. Hao, Z. Zhang, M. Jiang, and Y. Zhang, "Development of a new compound method to extract the five 
parameters of PV modules," Energy Conversion and Management, vol. 79, pp. 294-303, 2014.

[23] G. Ciulla, V. Lo Brano, V. Di Dio, and G. Cipriani, "A comparison of different one-diode models for the representation of I-V characteristic of a PV cell," Renewable and Sustainable Energy Reviews, vol. 32, pp. 684-696, 2014.

[24] W. De Soto, S. A. Klein, and W. A. Beckman, "Improvement and validation of a model for photovoltaic array performance," Solar Energy, vol. 80, no. 1, pp. 78-88, 2006.

[25] T. H. Jung, J. W. Ko, G. H. Kang, and H. K. Ahn, "Output characteristics of PV module considering partially reverse biased conditions," Solar Energy, vol. 92, pp. 214-220, 2013.

[26] M. A. de Blas, J. L. Torres, E. Prieto, and A. García, "Selecting a suitable model for characterizing photovoltaic devices," Renewable Energy, vol. 25, no. 3, pp. 371-380, 2002.

[27] A. Hadj Arab, F. Chenlo, and M. Benghanem, "Loss-of-load probability of photovoltaic water pumping systems," Solar Energy, vol. 76, no. 6, pp. 713-723, 2004.

[28] D. Sera, R. Teodorescu, and P. Rodriguez, "PV panel model based on datasheet values," in Proceedings of the IEEE International Symposium on Industrial Electronics (ISIE '07), pp. 23922396, Vigo, Spain, June 2007.

[29] Y. Sukamongkol, S. Chungpaibulpatana, and W. Ongsakul, "A simulation model for predicting the performance of a solar photovoltaic system with alternating current loads," Renewable Energy, vol. 27, no. 2, pp. 237-258, 2002.

[30] E. Karatepe, M. Boztepe, and M. Colak, "Neural network based solar cell model," Energy Conversion and Management, vol. 47, no. 9-10, pp. 1159-1178, 2006.

[31] H. Tian, F. Mancilla-David, K. Ellis, E. Muljadi, and P. Jenkins, "A cell-to-module-to-array detailed model for photovoltaic panels," Solar Energy, vol. 86, no. 9, pp. 2695-2706, 2012.

[32] J. Kumari and C. S. Babu, "Mathematical modeling and simulation of photovoltaic cell using matlab-simulink environment," International Journal of Electrical and Computer Engineering, vol. 2, no. 1, pp. 26-34, 2012.

[33] R. K. Kharb, S. L. Shimi, S. Chatterji, and M. F. Ansari, "Modeling of solar PV module and maximum power point tracking using ANFIS," Renewable and Sustainable Energy Reviews, vol. 33, pp. 602-612, 2014.

[34] A. Chouder, S. Silvestre, N. Sadaoui, and L. Rahmani, "Modeling and simulation of a grid connected PV system based on the evaluation of main PV module parameters," Simulation Modelling Practice and Theory, vol. 20, no. 1, pp. 46-58, 2012.

[35] S. Silvestre, A. Boronat, and A. Chouder, "Study of bypass diodes configuration on PV modules," Applied Energy, vol. 86, no. 9, pp. 1632-1640, 2009.

[36] G. H. Yordanov, O.-M. Midtgård, and T. O. Saetre, "Series resistance determination and further characterization of $\mathrm{c}-\mathrm{Si}$ PV modules," Renewable Energy, vol. 46, pp. 72-80, 2012.

[37] S. Chowdhury, G. A. Taylor, S. P. Chowdhury, A. K. Saha, and Y. H. Song, "Modelling, simulation and performance analysis of a PV array in an embedded environment," in Proceedings of the 42nd International Universities Power Engineering Conference (UPEC '07), pp. 781-785, September 2007.

[38] K. Nishioka, N. Sakitani, K.-I. Kurobe et al., "Analysis of the temperature characteristics in polycrystalline si solar cells using modified equivalent circuit model," Japanese Journal of Applied Physics, vol. 42, no. 12, pp. 7175-7179, 2003.

[39] JA. Gow and CD. Manning, "Development of a model for photovoltaic arrays suitable for use in simulation studies of solar energy conversion systems," in Proceedings of the 6th International Conference on Power Electronics and Variable Speed Drives, Conference Publication no. 429, pp. 69-74, September 1996.

[40] K.-I. Kurobe and H. Matsunami, "New two-diode model for detailed analysis of multicrystalline silicon solar cells," Japanese Journal of Applied Physics, vol. 44, no. 12, pp. 8314-8321, 2005.

[41] J. Hyvärinen and J. Karila, "New analysis method for crystalline silicon cells," in Proceedings of the Proceddings of the 3rd World Conference on Photovoltaic Energy Conversion, pp. 1521-1524, Osaka, Japan, May 2003.

[42] J. A. Gow and C. D. Manning, "Development of a photovoltaic array model for use in power-electronics simulation studies," IEE Proceedings: Electric Power Applications, vol. 146, no. 2, pp. 193-200, 1999.

[43] T. Chai and R. R. Draxler, "Root mean square error (RMSE) or mean absolute error (MAE)?-Arguments against avoiding RMSE in the literature," Geoscientific Model Development, vol. 7, no. 3, pp. 1247-1250, 2014. 

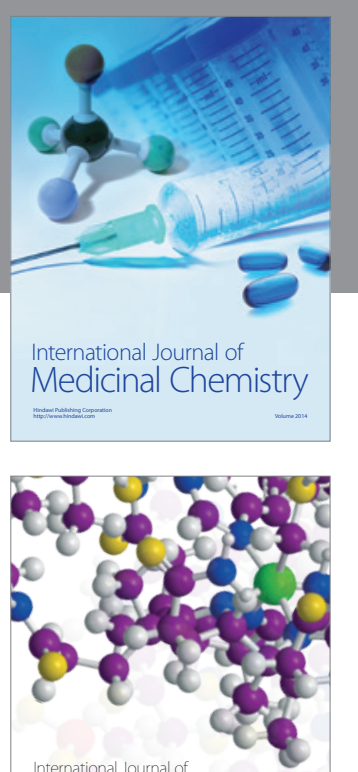

Carbohydrate Chemistry

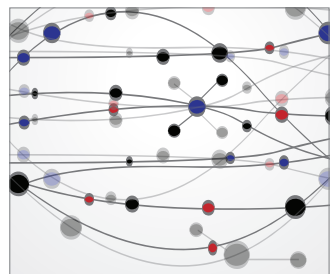

The Scientific World Journal
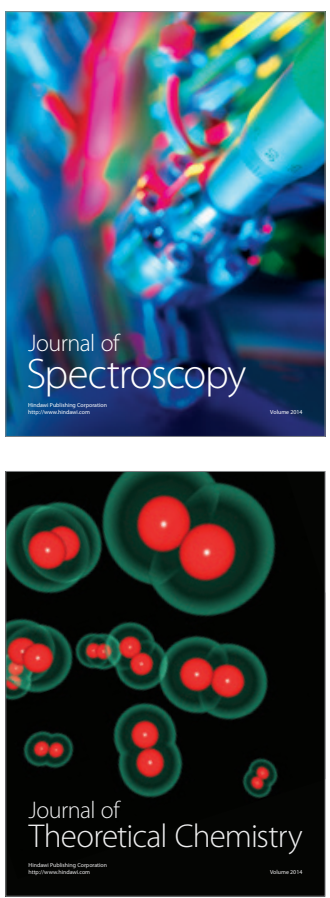
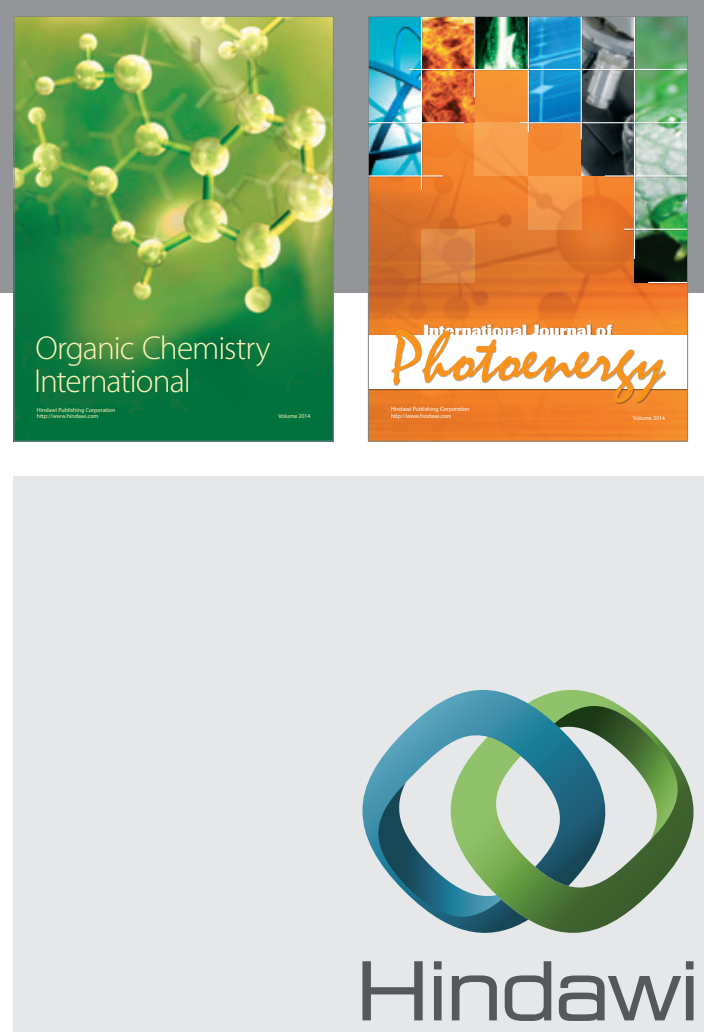

Submit your manuscripts at

http://www.hindawi.com

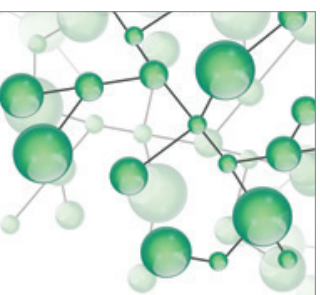

International Journal of

Inorganic Chemistry

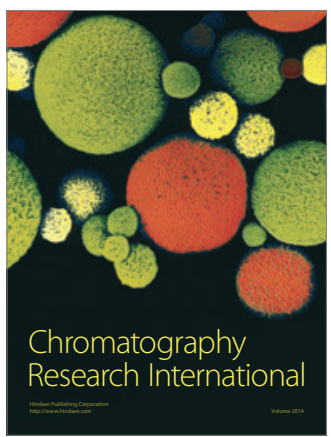

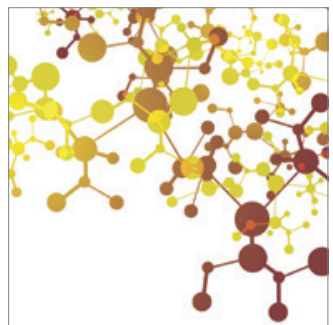

Applied Chemistry
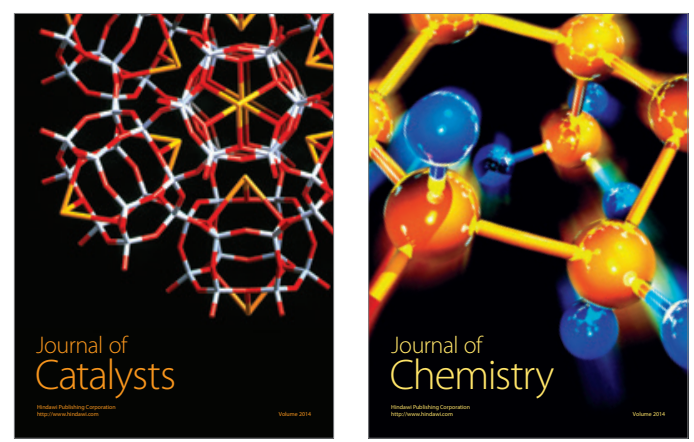
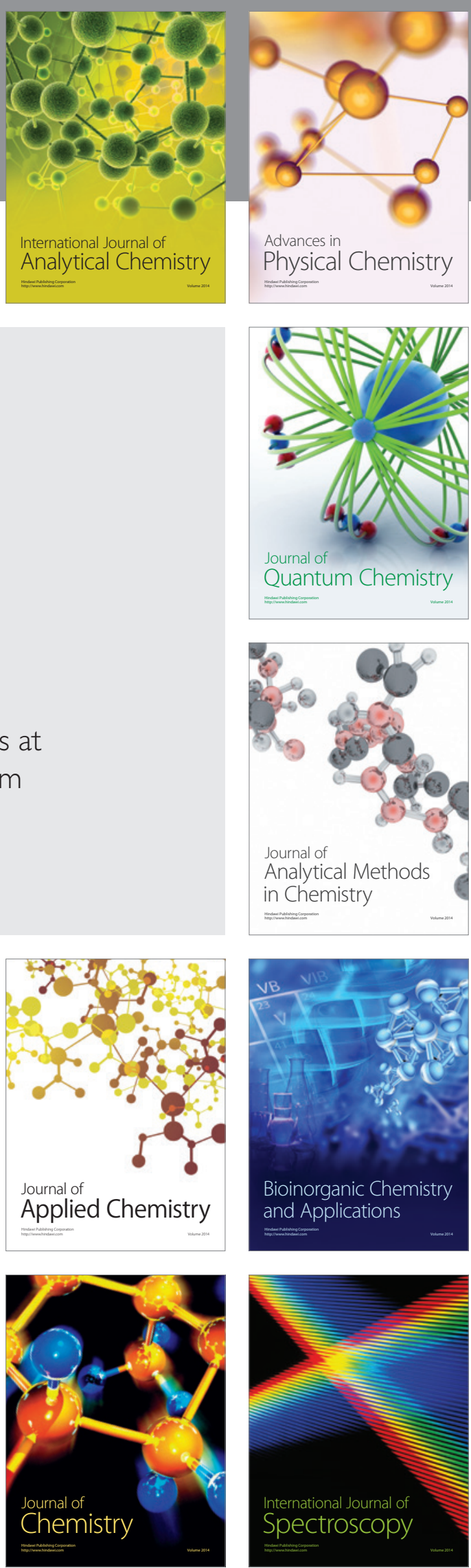